\title{
Pozytywna prognoza kryminologiczna jako materialna przesłanka warunkująca zastosowanie warunkowego zawieszenia wykonania kary. Uwagi na tle pojęcia „prognoza” oraz orzecznictwa sądów polskich
}

\author{
KATARZYNA WITKOWSKA-ROZPARA \\ ORCID: 0000-0002-4729-4697 \\ Katedra Kryminologii i Polityki Kryminalnej \\ Instytut Profilaktyki Społecznej i Resocjalizacji Wydziału Stosowanych Nauk \\ Społecznych i Resocjalizacji Uniwersytetu Warszawskiego
}

Warunkowe zawieszenie wykonania kary pozbawienia wolności zostało uregulowane w rozdziale VIII Kodeksu karnego, zatytułowanym „Środki związane z poddaniem sprawcy próbie"1. Przyjęta przez polskiego ustawodawcę nomenklatura skłania do refleksji nad charakterem normatywnym omawianej instytucji, podobnie zresztą jak dwóch innych, przewidzianych w rozdziale VIII k.k., to jest warunkowego umorzenia postępowania karnego oraz warunkowego zawieszenia wykonania kary. Próby zdefiniowania charakteru wszystkich trzech przywołanych rozwiązań prawnokarnych były podejmowane $\mathrm{w}$ doktrynie ${ }^{2}$. Na potrzeby

1 Zob. art. 69-76 k.k.

2 Zob. m.in. A. Marek, Pojęcie i formy probacji. Zagadnienia ogólne, [w:] System Prawa Karnego, t. 6. Kary i środki karne. Poddanie sprawcy próbie, red. M. Melezini, 
niniejszego opracowania przyjęto, że warunkowe zawieszenie wykonania kary nie jest probacją sensu stricto, a jedynie środkiem probacyjnym, które to pojęcie jest znaczeniowo szersze — zakłada bowiem, że sprawca poddawany jest próbie, ale bez obowiązku nakładania na niego dozoru kuratora ${ }^{3}$.

W doktrynie wskazuje się, że zastosowanie warunkowego zawieszenia wykonania kary jest możliwe w wypadku łącznego zaktualizowania się określonych przesłanek. Dwie z nich mają charakter formalny i zostały zdefiniowane przez ustawodawcę w art. 69 § 1 k.k. Zgodnie z przyjętymi w przywołanym unormowaniu regułami możliwe jest zawieszenie wykonania kary pozbawienia wolności orzeczonej w wymiarze do roku, o ile sprawca „w czasie popełnienia przestępstwa nie był skazany na karę pozbawienia wolności" 4 . Trzecia przesłanka ma charakter materialny i jak powszechnie przyjęto $\mathrm{w}$ doktrynie, wiąże się z koniecznością wykazania, iż wobec sprawcy zachodzi tak zwana pozytywna prognoza kryminologiczna ${ }^{5}$. Warto jednak zaznaczyć, że polski ustawodawca prawnokarny nie posługuje się wprost pojęciem ,,prognoza” ani też ,prognozowanie". Terminy te nie występują w obowiązującym Kodeksie karnym, co więcej — w samym art. 69 k.k., pojawia się jedynie sformułowanie akcentujące konieczność wykazania, iż zastosowanie warunkowego zawieszenia będzie ,wystarczające dla osiągnięcia wobec [...] [sprawcy — K.W.R.] celów kary, a w szczególności zapobieżenia powrotowi do

Warszawa 2010, s. 935-937; B. Kunicka-Michalska, [w:] System Prawa Karnego, t. 6, s. 938-1030; J. Skupiński, [w:] System Prawa Karnego, t. 6, s. 1030-1064; S. Lelental, [w:] System Prawa Karnego, t. 6, s. 1064-1142.

${ }^{3}$ A. Marek, op. cit., s. 935-937; szerzej na ten temat zob. K. Witkowska-Rozpara, Warunkowe zawieszenie wykonania kary — uwagi na tle obowiazujacej regulacji, praktyki orzeczniczej sadów polskich oraz nowelizacji Kodeksu Karnego (z moca obowiązująa od 1.07.2015), „Probacja” 2015, nr 2, s. 9-12.

${ }^{4}$ Zob. art. 69 § 1 k.k.; szerzej na ten temat zob. V. Konarska-Wrzosek, Komentarz do art. 69 k.k., [w:] Kodeks karny. Komentarz, red. V. Konarska-Wrzosek, wyd. 2, Warszawa 2018, online w SIP Lex (dostęp: 21.06.2019).

${ }^{5}$ Tak m.in. V. Konarska-Wrzosek, op. cit.; P. Hofmański, L. Paprzycki, A. Sakowicz, Komentarz do art. 69 k.k., [w:] Kodeks karny. Komentarz, red. M. Filar, wyd. 5, Warszawa 2016, online w SIP Lex (dostęp: 21.06.2019); T. Bojarski, Komentarz do art. 69 k.k., [w:] Kodeks karny. Komentarz, red. T. Bojarski, wyd. 7, Warszawa 2016, online w SIP Lex (dostęp: 21.06.2019). 
przestępstwa”, co jest niezwykle interesujące, zważywszy, że na gruncie regulacji dotyczących dwóch pozostałych środków związanych z poddaniem sprawcy próbie ustawodawca mówi wprost bądź o uzasadnionym przypuszczeniu (art. 66 k.k.) ${ }^{6}$, bądź o uzasadnionym przekonaniu (art. 77 k.k. $)^{7}$ dotyczącym dalszego (przyszłego) zachowania się sprawcy.

Jak wskazuje Grzegorz Goniewicz, tego rodzaju rozróżnienie pojęć mogłoby sugerować, że stopień przeświadczenia sądu w zakresie pozytywnych rokowań odnośnie do przyszłego postępowania sprawcy na gruncie trzech przywołanych instytucji kształtuje się odmiennie ${ }^{8}$. Biorąc pod uwagę wykładnię językową, najwyższy stopień przeświadczenia winien aktualizować się w odniesieniu do warunkowego przedterminowego zwolnienia, powstaje jednak pytanie, jak w takim razie ma się kształtować „poziom” przeświadczenia sędziego co do przyszłego zachowania sprawcy na gruncie instytucji warunkowego zawieszenia wykonania kary, skoro w tym konkretnym wypadku ustawodawca nie posłużył się na gruncie regulacji kodeksowych żadnym z wymienionych pojęć, to znaczy — ani nie wskazał na konieczność wystąpienia uzasadnionego „przeświadczenia”, ani też uzasadnionego ,przekonania”9.

Jak podkreśla przywołany autor, wydaje się, że w odniesieniu do warunkowego zawieszenia wykonania kary „stopień” przeświadczenia sądu odnośnie do przyszłego zachowania się sprawcy winien odpowiadać temu,

${ }^{6}$ Art. 66 § 1 k.k. stanowi: „Sąd może warunkowo umorzyć postępowanie karne, jeżeli wina i społeczna szkodliwość czynu nie są znaczne, okoliczności jego popełnienia nie budzą wątpliwości, a postawa sprawcy niekaranego za przestępstwo umyślne, jego właściwości i warunki osobiste oraz dotychczasowy sposób życia u z a s a d n i a ją przypuszczenie [wyr. - K.W.R.], że pomimo umorzenia postępowania będzie przestrzegał porządku prawnego, w szczególności nie popełni przestępstwa”.

${ }^{7}$ Art. $77 \S 1$ k.k. stanowi: „Skazanego na karę pozbawienia wolności sąd może warunkowo zwolnić z odbycia reszty kary tylko wówczas, gdy jego postawa, właściwości i warunki osobiste, okoliczności popełnienia przestępstwa oraz zachowanie po jego popełnieniu i w czasie odbywania kary uzasadniają przekonanie [wyr. K.W.R.], że skazany po zwolnieniu będzie stosował się do orzeczonego środka karnego lub zabezpieczającego i przestrzegał porządku prawnego, w szczególności nie popełni ponownie przestępstwa".

${ }^{8}$ G. Goniewicz, Pozytywna prognoza kryminologiczna jako przesłanka stosowania środków probacyjnych, „Czasopismo Prawa Karnego i Nauk Penalnych” 2017, nr 7, s. 120.

${ }^{9}$ Ibidem, s. 120-121. 
który zachodzi w wypadku warunkowego umorzenia postępowania karnego, ponieważ

$\mathrm{z}$ systemowego punktu widzenia orzekanie w przedmiocie warunkowego zawieszenia jest bliższe orzekaniu o warunkowym umorzeniu. Oba te środki są bowiem stosowane przez sąd orzekający w przedmiocie odpowiedzialności karnej i stanowią bezpośrednią reakcję na popełniony czyn zabroniony - w odróżnieniu do warunkowego zwolnienia, stosowanego przez sąd penitencjarny na etapie wykonania kary $[\ldots]^{10}$.

Inną kwestią jest to, czy w odniesieniu do tego ostatniego zasadne jest — kierowane do sądu penitencjarnego — oczekiwanie, aby ten miał przekonanie (a może i pewność?) co do tego, jak zachowa się sprawca warunkowo zwolniony z zakładu karnego ${ }^{11}$. Pytanie to wydaje się tym bardziej istotne, biorąc pod uwagę, że konstruowanie prognozy kryminologicznej w odniesieniu do przedterminowego warunkowego zwolnienia ogranicza się w istocie do czynności realizowanych przez sąd (a nie specjalistów z zakresu kryminologii czy psychologii), które bazują w gruncie rzeczy na ,rutynowej ocenie materiału dowodowego zebranego w aktach sprawy [...]. Nie jest zatem wynikiem specjalistycznych badań osobopoznawczych [...]"12. Gdyby jednak nawet przyjąć, że w istocie do zastosowania warunkowego zwolnienia wymagane jest pr z e k o n a n i e sądu co do przyszłego postępowania sprawcy, czy racjonalne byłoby w takiej sytuacji mówienie w ogóle o prognozie (kryminologicznej), co więcej — czy uzasadnione byłoby skierowanie sprawcy na okres próby i obłożenie go obowiązkami, skoro sąd ma pewność, że sprawca na wolności będzie przestrzegał porządku prawnego ${ }^{13}$

10 Ibidem, s. 122.

$11 \mathrm{Na}$ problem ten trafnie zwrócił uwagę Tomasz Kalisz, wyraźnie akcentując, iż z założenia ,prognozowanie” nie implikuje przecież pewności co do przyszłego zachowania sprawcy; zob. idem, Warunkowe zwolnienie z reszty kary pozbawienia wolności z perspektywy problemów z ustaleniem treści i kierunku prognozy kryminologicznej, „Nowa Kodyfikacja Prawa Karnego” 30, 2013, s. 180.

12 P. Stępniak, Udziat skazanego w ksztattowaniu prognozy kryminologicznej, „Przegląd Więziennictwa Polskiego" 2018, nr 61, s. 54.

13 T. Kalisz, op. cit., s. 180. Oczekiwanie, że sąd penitencjarny, orzekając w przedmiocie warunkowego przedterminowego zwolnienia, będzie przekonany, że sprawca na wolności będzie przestrzegał porządku prawnego wydaje się nieco „wyolbrzymione” także w kontekście jakości stawianych „prognoz” — w literaturze przedmiotu wskazuje się bowiem, iż pomimo nałożonego na organ rozstrzygający obowiązku przeanalizowania 
Co ciekawe, analiza orzecznictwa sądów polskich w zakresie stosowania art. 69 k.k. prowadzi do wniosku, iż organy rozstrzygające w zasadzie utożsamiają stawianie prognozy kryminologicznej z powzięciem przez sąd przek on ania o kształcie dalszego postępowania sprawcy. W wyroku Sądu Apelacyjnego we Wrocławiu z dnia 26 lipca 2017 roku organ rozstrzygający stwierdził, że konstrukcja warunkowego zawieszenia wykonania kary opiera się na zmiennych prognostycznych, pozwalających przyjąć, że cele kary pozbawienia wolności będą zrealizowane, mimo iż sprawcy nie zostanie wymierzona kara w postaci bezwzględnej. W przywołanym judykacie sąd uznał, że komentowana instytucja stanowi

swoisty środek polityki karnej wobec sprawców nadających się do oddziaływań resocjalizacyjnych w warunkach wolnościowych wobec istnienia po ich stronie uzasadnionego pr z e k o n a n i a [wyr. - K.W.R.], że nie powrócą na drogę przestępstwa ${ }^{14}$.

Warto zaznaczyć, że cytowany organ powołał się w swoim rozstrzygnięciu na wyrok Sądu Apelacyjnego w Lublinie z dnia 27 maja 2015 roku, w którym także odwołano się do koncepcji uzasadnionego przekonania $^{15}$. Wskazanie na przekonanie sądu pojawia się również $\mathrm{w}$ wyroku Sądu Okręgowego w Poznaniu z dnia 20 marca 2015 roku. W rozstrzygnięciu tym sąd uznał, że decydując się na warunkowe zawieszenie wykonania kary, organ rozstrzygający „,musi nabrać p r ze k o n a n i a [wyr. — K.W.R.], że sprawca nie powróci do przestępstwa i wykonanie wymierzonej mu kary nie będzie konieczne dla wdrożenia go do przestrzegania porządku prawnego", argumentując jednocześnie, że wskazane przekonanie musi opierać się na ocenie zmiennych określonych w art. 69

wszystkich wymienionych w art. $77 \S 1$ k.k. przesłanek w praktyce często w ogóle nie są uwzględniane te, które dotyczą właściwości i warunków osobistych sprawcy oraz jego postawy, bądź też w podejmowanych rozstrzygnięciach sądy ograniczają się do wskazania określonej przesłanki ustawowej, bez wskazania, jakie cechy sprawcy uwzględniono przy wydaniu decyzji określonej treści - szerzej zob. G. Goniewicz, Orzekanie o warunkowym przedterminowym zwolnieniu z odbywania reszty kary pozbawienia wolności po nowelizacji Kodeksu karnego, „Palestra” 2015, nr 7-8, s. 81.

14 Wyrok Sądu Apelacyjnego we Wrocławiu z dnia 26 lipca 2017 roku, II AKa 178/17, online w SIP Lex (dostęp: 27.06.2019).

15 Zob. wyrok Sądu Apelacyjnego w Lublinie z dnia 27 maja 2015 roku, II AKa 97/15, online w SIP Lex (dostęp: 27.06.2019). 
$\S 2$ k.k. ${ }^{16}$ Przywołany judykat jest tym bardziej interesujący, że w jego uzasadnieniu posłużono się wręcz pojęciem rękojmi (argumentując w tym konkretnym wypadku, iż „oskarżony nie daje rękojmi, iż w przyszłości ponownie nie popełni przestępstwa”) ${ }^{17}$, zgodnie zaś z leksykalnym znaczeniem tego terminu ,rękojmia” oznacza ,poręczenie, zagwarantowanie czegoś"18, „gwarancję, zabezpieczenie, pewność"19.

Jeszcze bardziej zaskakującą formułę można odnaleźć w wyroku Sądu Rejonowego w Puławach z dnia 22 maja 2019 roku, na łamach którego sąd, zawieszając wykonanie kary, stwierdził, że

wymierzył karę oraz środki karne adekwatne do stopnia społecznej szkodliwości czynu i winy oskarżonej, które spowodują, że oskarżona nie popełni [wyr. K.W.R.] więcej podobnego czynu, a dla innych będą stanowić przestrogę ${ }^{20}$.

Jak się wydaje, na gruncie przywołanego stanu faktycznego organ rozstrzygający uznał wręcz, że ma pewność co do tego, jak skazana zachowa się w przyszłości.

Sygnalizowane wcześniej operowanie pojęciem przekonania w odniesieniu do prognozy kryminologicznej można spotkać w wielu rozstrzygnięciach sądów polskich, między innymi w wyroku Sądu Apelacyjnego w Gdańsku z dnia 27 października 2016 roku (,przekonanie sądu musi być oparte") ${ }^{21}$, w wyroku Sądu Apelacyjnego we Wrocławiu z dnia 16 maja 2018 roku (,sąd musi nabrać przekonania”) 22 czy w wyroku Sądu Rejonowego w Kętrzynie z dnia 17 maja 2019 roku (,sąd doszedł do przeko-

16 Wyrok Sądu Okręgowego w Poznaniu z dnia 20 marca 2015 roku, IV Ka 166/15, online w SIP Lex (dostęp: 27.06.2019).

${ }^{17}$ Ibidem.

${ }^{18}$ Rękojmia, [hasło w:] Stownik języka polskiego PWN, https://sjp.pwn.pl/sjp/rekojmia;2515379.html (dostęp: 27.06.2019).

19 Rękojmia, [hasło w:] Stownik języka polskiego, red. W. Doroszewski, https://sjp. pwn.pl/doroszewski/rekojmia;5490144.html (dostęp: 27.06.2019).

${ }^{20}$ Wyrok Sądu Rejonowego w Puławach z dnia 22 maja 2019 roku, II K 1145/18, online w SIP Lex (dostęp: 27.06.2019).

${ }^{21}$ Wyrok Sądu Apelacyjnego w Gdańsku z dnia 27 października 2016 roku, II AKa 162/16, online w SIP Lex (dostęp: 27.06.2019).

${ }^{22}$ Wyrok Sądu Apelacyjnego we Wrocławiu z dnia 16 maja 2018 roku, II AKa 101/18, online w SIP Lex (dostęp: 27.06.2019). 
nania") ${ }^{23}$. Co ciekawe, także wtedy, gdy sąd stawia negatywną prognozę kryminologiczną, często posługuje się pojęciem przekonania, argumentując, dlaczego jest p r zek o n a ny, że sprawca nie zasługuje na możliwość wymierzenia mu kary w zawieszeniu. Z takim ujęciem można spotkać się między innymi w uzasadnieniu wyroku Sądu Rejonowego w Giżycku z dnia 29 kwietnia 2019 roku, na łamach którego organ rozstrzygający w sprawie stwierdził, iż

doszedł do przekonania, że z uwagi na popełnienie przez oskarżonego kolejnych przestępstw [...] jedynie bezwzględna kara pozbawienia wolności pozwoli na osiągnięcie w stosunku do jego osoby celów kary [...] oraz że nie zachodzą szczególne okoliczności dające możliwość warunkowego zawieszenia wykonania tak orzeczonej kary pozbawienia wolności $[\ldots]^{24}$.

Jak zatem widać, mimo że na poziomie doktryny wskazuje się, iż sąd, analizując możliwość zawieszenia wykonania kary, winien operować przeświadczeniem co do kształtu dalszego postępowania sprawcy, organy rozstrzygające — przynajmniej w ujęciu literalnym — odwołują się do pojęcia p r z e k o n a n i a, które - jak sygnalizowano powinno zakładać wyższy stopień uzasadnienia i uprawdopodobnienia stawianej prognozy. Na marginesie warto dodać, że takie z kolei ujęcie siłą rzeczy aktualizuje pytanie o jakość stawianych prognoz oraz ich konkretne podstawy.

Nie ulega wątpliwości, że prognozowanie kryminologiczne ma stosunkowo długie tradycje i w zasadzie od początku swojego istnienia opierało się na odwołaniu do gromadzonych przez sędziów czy funkcjonariuszy Służby Więziennej doświadczeń własnych oraz — niejako przy okazji — ,przecenianiu” wiedzy wynikającej ze zdobytego doświadczenia. Warto także podkreślić, że podmioty stawiające prognozę „stykają się ze sprawcą w sytuacji wyjątkowej, która nie zawsze stanowi należytą podstawę do prawidłowego wnioskowania w odniesieniu do przyszłości"25. Z kolei prawidłowy dobór reakcji prawnokarnej na popełniony przez sprawcę czyn zabroniony jest kwestią kluczową, nierzadko bowiem to właśnie pierwsze

23 Wyrok Sądu Rejonowego w Kętrzynie z dnia 17 maja 2019 roku, II K 195/19, online w SIP Lex (dostęp: 27.06.2019).

24 Wyrok Sądu Rejonowego w Giżycku z dnia 29 kwietnia 2019 roku, II K 410/17, online w SIP Lex (dostęp: 27.06.2019).

25 P. Zakrzewski, Zagadnienie prognozy kryminologicznej, Warszawa 1964, s. 7. 
podejmowane wobec sprawcy rozstrzygnięcie o rodzaju i formie reakcji karnej będzie wpływać na całą jego przyszłość, a nieodpowiednio dobrana kara może w dalszej perspektywie spowodować bardzo istotne konsekwencje $^{26}$. Jak zatem widać, każdorazowa decyzja rozstrzygająca o formie reakcji prawnokarnej stosowanej wobec sprawcy czynu zabronionego musi być decyzją przemyślaną, uzasadnioną; w wypadku zaś decyzji o warunkowym zawieszeniu wykonania orzeczonej sprawcy kary tego rodzaju rozstrzygnięcie powinno być poprzedzone przyjęciem przez sąd, że w odniesieniu do sprawcy zachodzi pozytywna prognoza kryminologiczna.

Powstaje jednak pytanie, co tak naprawdę oznacza zwrot ,pozytywna prognoza kryminologiczna" i opierając się o jakie czynniki, ma być ona przyjmowana.

W literaturze wskazuje się, że prognoza kryminologiczna bazuje na „okolicznościach wskazujących na najbardziej prawdopodobny wariant zachowania się w przyszłości”27. Sam termin ,prognozowanie” odzwierciedla natomiast próbę nakreślenia — po uwzględnieniu zarejestrowanych tendencji i określonych praw — prawdopodobnych ,wariantów przyszłości", jak też rozpoznania zmiennych, warunkujących ziszczenie się danej konfiguracji ${ }^{28}$. Warto także zaznaczyć, że w odniesieniu do stawianych prognoz społecznych, w tym prognoz kryminologicznych dotyczących zachowania się sprawcy, trudno w zasadzie określić cezurę czasową, dla której stawiana jest prognoza. W prognozie mówi się bowiem o przyszłym zachowaniu się sprawcy, co jednak nie odpowiada na pytanie, o jaką konkretnie przyszłość chodzi - bliższą czy dalszą, mierzoną w miesiącach czy latach? ${ }^{29}$ Być może pewną wskazówką w tym zakresie jest wyznaczana przez sąd podejmujący decyzję o warunkowym zawieszeniu wykonania kary długość okresu próby, nie jest to jednak zmienna, na której podstawie można wyprowadzić konkretne, wiążące wnioski, zwłaszcza zaś w tych sytuacjach, w których sąd niejako automatycznie

\section{Ibidem, s. 12.}

27 V. Voninelić, B. Uglješić, Indywidualna prognoza antyspołecznych zachowań psychopatów, socjopatów i umysłowo chorych, [w:] Prognozowanie kryminologiczne, red. A. Krukowski, Warszawa 1975, s. 170.

28 A. Siciński, [w:] Studia z teorii i metodologii prognozowania społecznego. Prognozowanie zachowań, red. A. Siciński, A. Raźniewski, Warszawa 1976, s. 8.

29 Ibidem, s. 9. 
jest zobligowany przyjąć dłuższy okres próby (na przykład gdy zawiesza wykonanie kary orzeczonej sprawcy młodocianemu, wobec którego przyjął pozytywną prognozą kryminologiczną pozwalającą na zastosowanie komentowanej instytucji) ${ }^{30}$.

$\mathrm{Na}$ gruncie rozwiązań normatywnych przyjętych w obowiązującym Kodeksie karnym przy stawianiu prognozy sąd zobowiązany jest przeanalizować pewne zmienne, przy czym wskazany w art. $69 \S 2$ k.k. katalog tych zmiennych nie ma charakteru zamkniętego, o czym przesądza użyty przez ustawodawcę zwrot „,przede wszystkim”31. Podobne rozwiązanie można spotkać w ustawodawstwach karnych innych krajów. Zgodnie z § 56 niemieckiego kodeksu karnego sąd, podejmując decyzję w przedmiocie warunkowego zawieszenia wykonania kary, ma wziąć pod uwagę w s zc ze gólnoś c i właściwości osobiste (charakter, osobowość) sprawcy, jego dotychczasowe życie, okoliczności czynu, zachowanie się sprawcy po przestępstwie, jego ogólne warunki życiowe oraz skutki, jakich oczekuje się dla sprawcy po zawieszeniu kary:

Dabei sind namentlich [wyr. - K.W.R.] die Persönlichkeit des Verurteilten, sein Vorleben, die Umstände seiner Tat, sein Verhalten nach der Tat, seine Lebensverhältnisse und die Wirkungen zu berücksichtigen, die von der Aussetzung für ihn zu erwarten $\operatorname{sind}^{32}$.

W sposób bardzo zbliżony kwestię związaną z katalogiem zmiennych badanych przez sąd reguluje czeski kodeks karny, który w art. 81 wskazuje, iż sąd bierze pod uwagę osobę sprawcy i dotyczące go okolicz-

${ }^{30}$ Zob. art. $70 \S 2$ k.k. W orzecznictwie można spotkać rozstrzygnięcia, które wprost korelują długość okresu próby z prognozą w ten sposób, iż wskazują, że im pewniejsza jest stawiana prognoza, tym okres próby winien być krótszy; $\mathrm{z}$ taką formułą spotkać można się między innymi na gruncie wyroku Sądu Apelacyjnego we Wrocławiu z dnia 29 maja 2014 roku, w którym sąd uznał, iż „okres próby ma zweryfikować trafność postawionej prognozy kryminologicznej. Stopień pewności prognozy decyduje o okresie próby. Okres próby jest krótszy, gdy pewniejsza jest prognoza kryminologiczna" — wyrok Sądu Apelacyjnego we Wrocławiu z dnia 29 maja 2014 roku, II AKa 136/14, online w SIP Lex (dostęp: 27.06.2019).

31 Szerzej zob. A. Zoll, Komentarz do art. 69 k.k., [w:] Kodeks karny. Część ogólna, t. 1, cz. 2. Komentarz do art. 53-116, red. W. Wróbel, A. Zoll, wyd. 5, Warszawa 2016, online w SIP Lex (dostęp: 30.06.2019).

32 Zob. § 56 Strafgesetzbuch (StGB), https://www.gesetze-im-internet.de/stgb (dostęp: 30.06.2019). 
ności, w szczególności jego dotychczasowe życie i środowisko, w którym mieszka i pracuje:

Soud může podmíněně odložit výkon trestu odnětí svobody nepřevyšujícího tři léta, jestliže vzhledem $k$ osobě a poměrům pachatele, zejména s přihlédnutím $k$ jeho dosavadnímu životu a prostředí, ve kterém žije a pracuje, a k okolnostem případu má důvodně za to, že k působení na pachatele, aby vedl rádný život, není třeba jeho výkonu ${ }^{33}$.

Jak więc widać, pozostawienie sądowi możliwości uwzględnienia także innych zmiennych w procesie stawiania prognozy kryminologicznej jest rozwiązaniem stosunkowo powszechnym i należy przyjąć, że uzasadnionym, zważywszy na fakt, że prognoza nie ma być konstruowana in abstracto — przeciwnie, ma dotyczyć danego sprawcy, który realizował znamiona konkretnego czynu zabronionego w określonych okolicznościach. Sąd ma zatem prawo badać i uwzględniać wszystkie zmienne, które w odniesieniu do danego sprawcy czynu i przyjmowanej wobec niego prognozy uzna za istotne.

„Składowe” poszczególnych badanych przez sąd zmiennych były już przedmiotem wielu analiz w doktrynie. Tytułem przypomnienia należy wskazać, że najczęściej pod pojęciem „postawa sprawcy” rozumie się generalny stosunek sprawcy do rzeczywistości, w której żyje (w tym do innych ludzi, systemu wartości przyjętego w danej społeczności czy nakładanych na niego obowiązków) ${ }^{34}$. „,Warunki i właściwości osobiste” wiążą się z kolei z koniecznością uwzględnienia bardzo wielu czynników, między innymi wieku sprawcy, osobowości (charakteru), poziomu wrażliwości, empatii, nałogów, stanu cywilnego, konieczności łożenia na utrzymanie członka(-ów) rodziny, wykształcenia, wykonywanego przez sprawcę zawodu czy - w wypadku sprawcy bezrobotnego — przypisywanych mu możliwości zarobkowych ${ }^{35}$. „Dotychczasowy sposób życia” zakłada ogólną ocenę tego, w jaki sposób sprawca funkcjonuje w przestrzeni społecznej: czy respektuje normy społeczne, czy realizuje obowiązki wynikające

33 Zob. 81 Zákon č. 40/2009 Sb. (Zákon trestní zákoník), https://aplikace.mvcr.cz/ sbirka-zakonu/ViewFile.aspx?type=c\&id=5405 (dostęp: 30.06 .2019$)$.

34 V. Konarska-Wrzosek, Ustawowe przesłanki stosowania warunkowego zawieszenia wykonania kary po nowelizacji kodeksu karnego, [w:] Warunkowe zawieszenie wykonania kary w założeniach nowej polityki karnej, red. A. Adamski, M. Berent, M. Leciak, Warszawa 2016, s. 174.

35 Ibidem.

Nowa Kodyfikacja Prawa Karnego 53, 2019

(C) for this edition by CNS 
z wykonywanej pracy, a nawet — w jaki sposób odpoczywa, ,gospodaruje" czasem wolnym ${ }^{36}$. Ostatnia ze wskazanych przez ustawodawcę zmiennych wiąże się z koniecznością prześledzenia postępowania sprawcy już po zrealizowaniu przez niego znamion czynu zabronionego. W tym aspekcie istotne znaczenie mają takie zachowania, jak starania o naprawienie szkody, próby pogodzenia/pojednania się z pokrzywdzonym czy też wyrażany przez sprawcę autentyczny żal ${ }^{37}$.

Nietrudno zauważyć, że wskazane zmienne mają charakter zindywidualizowany i są niejako rozpatrywane w skali mikro. Dla porównania czynniki wpływające na prognozę przestępczości jako takiej badane są na szerszą skalę, a już sam charakter niektórych z nich wymaga spojrzenia z perspektywy makro. W literaturze podejmowane są próby klasyfikowania zmiennych uwzględnianych przy prognozowaniu przestępczości jako zjawiska społecznego. Wyróżniane są między innymi zmienne ekonomiczno-kulturowe (na przykład skala bezrobocia, skala bezdomności, poziom rozwoju gospodarczego państwa, stopa bogactwa społeczeństwa), psychologiczno-socjologiczne (na przykład system wartości przyjmowany w danej społeczności, skala demoralizacji osób młodych, pozycja Kościoła i znaczenie norm religijnych oraz kodeksu zasad moralnych czy stabilność więzi rodzinnych i instytucji rodziny), demograficzne (na przykład ruchy migracyjne, struktura społeczna z uwzględnieniem takich kategorii, jak płeć czy wiek) oraz zmienne prawno-administracyjne, które dotyczą takich kwestii, jak efektywność pracy organów ścigania, stabilność systemu normatywnego, kształt systemu danin publicznoprawnych czy koncepcji resocjalizacji w jednostkach penitencjarnych ${ }^{38}$. W samym zresztą prognozowaniu przestępczości wyodrębnia się dwa kluczowe typy prognoz - dotyczące przestępczości pierwotnej oraz te, które odnoszą się do przestępczości powrotnej, a w ramach obu typów prognozowanie może dotykać wielu kwestii, chociażby struktury przestępczości czy za-

36 Ibidem, s. 175.

${ }^{37}$ Ibidem.

38 B. Hołyst, Czynniki determinujące prognozę przestępczości, [w:] Prognozowanie kryminologiczne w wymiarze społecznym, red. B. Hołyst, t. 1. Metodologia. Analiza. Tendencje rozwojowe, Warszawa 2017, s. 232. 
kładanej efektywności przyjmowanych narzędzi zapobiegania zjawiskom kryminogennym ${ }^{39}$.

Wracając do problematyki indywidualnej prognozy kryminologicznej, warto zaznaczyć, że poziom „uszczegółowienia” danego badania zależeć będzie od okoliczności konkretnej sprawy. Nie ulega jednak wątpliwości, że sąd winien wykazać, że na podstawie przeanalizowanych „składowych” zasadne jest uznanie, iż nie zachodzi konieczność wykonania orzeczonej sprawcy kary, co więcej — racjonalne jest przyjęcie, że mimo braku egzekucji kary jej cele zostaną osiągnięte. Problem, który aktualizuje się w tym miejscu, dotyczy tego, czy rozważając możliwość warunkowego zawieszenia wykonania kary w odniesieniu do konkretnego sprawcy, sąd kształtując prognozę i w konsekwencji decyzję o zawieszeniu kary, winien kierować się także ogólnymi dyrektywami wymiaru kary sformułowanymi w art. 53 k.k.

Prezentowane zarówno w doktrynie, jak i na gruncie orzecznictwa stanowiska nie są w odniesieniu do postawionego pytania jednolite. Wydaje się, że przyczynkiem do dyskusji stał się fakt, iż przyjęty na gruncie art. 69 k.k. katalog przesłanek nie posługuje się znaną poprzednio obowiązującej regulacji zmienną dotyczącą prewencji ogólnej — art. 73 $\S 2$ k.k. z 1969 roku in fine stanowił: ,sąd bierze również pod uwagę, czy względy na społeczne oddziaływanie kary nie przemawiają przeciwko warunkowemu zawieszeniu jej wykonania" ${ }^{40}$. Część przedstawicieli doktryny stoi na stanowisku, iż mimo że aktualna regulacja nie zawiera wskazania na względy w zakresie prewencji ogólnej, sąd stosując warunkowe zawieszenie wykonania kary, winien uwzględniać dyrektywy wymiaru kary z art. 53 k.k., a wśród nich wzgląd na społeczne oddziaływanie kary ${ }^{41}$. Ujęcie tego rodzaju znajduje odzwierciedlenie w wyroku Sądu Apelacyjnego w Łodzi z dnia 23 lipca 2015 roku, w którym to or-

39 B. Hołyst, Podstawy i zakres indywidualnej prognozy kryminologicznej, „Probacja” 2013, nr 1, s. 6 .

${ }^{40}$ G. Łabuda, [w:] Kodeks karny. Część ogólna. Komentarz, red. J. Giezek, wyd. 2, Warszawa 2012, online w SIP Lex (dostęp: 7.07.2019); zob. także art. $73 \S 2$ ustawy z dnia 19 kwietnia 1969 roku — Kodeks karny (Dz.U. z 1969 r. Nr 13, poz. 94 ze zm.).

41 Tak m.in. G. Łabuda, op. cit.; zob. także J. Skupiński, [w:] System Prawa Karnego, t. 6. s. $1054 \mathrm{n}$. 
gan rozstrzygający, powołując się zresztą na wyrok Sądu Apelacyjnego w Lodzi z dnia 13 listopada 2000 roku, stwierdził jednoznacznie, iż

chcąc wymierzyć karę z warunkowym zawieszeniem jej wykonania, sąd zobowiązany jest brać pod uwagę dyrektywy sądowego wymiaru kary określone w art. 53 k.k. W ramach tych dyrektyw sąd musi wziąc pod uwagę potrzeby w zakresie kształtowania świadomości prawnej społeczeństwa. Zawieszenie wykonania orzeczonej kary nie powinno zaś rodzić w opinii społecznej przekonania, że sprawca przestępstwa pozostał w zasadzie bezkarny ${ }^{42}$.

Warto zaznaczyć, że w przywołanym wyroku Sądu Apelacyjnego w Łodzi z 2000 roku organ rozstrzygający odniósł się przy okazji do charakteru warunkowego zawieszenia wykonania kary, uznając, iż jest to specyficzna postać wymiaru kary, swoista normatywna reakcja na czyn zabroniony, a decyzja o zastosowaniu wobec sprawy komentowanej instytucji jest ,integralną częścią orzeczenia o karze"43. Jak podkreśla Andrzej Zoll, tego rodzaju ujęcie zdaje się dominować w praktyce orzeczniczej sądów polskich, a jednocześnie wyraźnie wskazuje na to, iż sądy uznają warunkowe zawieszenie wykonania kary za swoisty, odrębny rodzaj kary ${ }^{44}$. Konstatacja ta jest tym bardziej ciekawa, jeśli uwzględni się wyniki prze-

42 Wyrok Sądu Apelacyjnego w Łodzi z dnia 23 listopada 2015 roku, II A Ka 111/15, online w SIP Lex (dostęp: 7.07.2019); zob. także wyrok Sądu Apelacyjnego w Łodzi z dnia 13 listopada 2000 roku, II AKa 217/00, online w SIP Lex (dostęp: 7.07.2019). Wzgląd na prewencję ogólną można odnaleźć również w przywoływanym wcześniej wyroku Sądu Okręgowego w Poznaniu z dnia 20 marca 2015 roku, w którym to sąd, mimo iż nie wskazał wprost na dyrektywy wymiaru kary z art. 53 k.k., uznał, że — biorąc pod uwagę negatywną prognozę kryminologiczną — wymierzenie sprawcy kary bez zawieszenia jest pożądane także z tego względu, iż „będzie sygnałem dla społeczeństwa, że taka osoba [sprawca, który kolejny raz popełnił przestępstwo umyślne - K.W.R.] spotyka się z surowszą reakcją wymiaru sprawiedliwości niż ten, kto popełnia czyn zabroniony po raz pierwszy" - wyrok Sądu Okręgowego w Poznaniu z dnia 20 marca 2015 roku, IV Ka 166/15, online w SIP Lex (dostęp: 1.07.2019). Odwołanie bezpośrednie do art. 53 k.k. i prewencji ogólnej miało z kolei miejsce w wyroku Sądu Rejonowego w Toruniu z dnia 13 maja 2019 roku, w którym to sąd, orzekając sprawcy karę w zawieszeniu, uznał, iż tego rodzaju rozstrzygnięcie umożliwi realizację celów wychowawczych i poprawczych, ,a nadto zrealizuje funkcje w zakresie kształtowania świadomości prawnej społeczeństwa" - wyrok Sądu Rejonowego w Toruniu z dnia 13 maja 2019 roku, VIII K 193/19, online w SIP Lex (dostęp: 7.07.2019).

${ }^{43}$ Wyrok Sądu Apelacyjnego w Łodzi z dnia 13 listopada 2000 roku, II AKa 217/00, online w SIP Lex (dostęp: 7.07.2019).

${ }^{44}$ A. Zoll, [w:] Kodeks karny. Część ogólna, t. 1, cz. 2. 
prowadzonych w 2017 roku badań dotyczących oceny funkcjonowania warunkowego zawieszenia wykonania kary po nowelizacji z 2015 roku. Na pytanie ,Jak w Pana/Pani ocenie wygląda proces decydowania przez sąd o wymierzeniu kary pozbawienia wolności w warunkowym zawieszeniu jej wykonania?" blisko $70 \%$ badanych (w tym ponad $70 \%$ sędziów) wskazało, że sąd najpierw weryfikuje, czy może zastosować komentowane rozwiązanie, a dopiero następnie ustala wysokość kary ${ }^{45}$. Jakkolwiek objęta badaniem grupa nie była znaczna (103 osoby) i trudno uznać ją za reprezentatywną, uzyskany w toku badania wynik skłania do dalszych refleksji - zarówno w zakresie oceny charakteru warunkowego zawieszenia wykonania kary, znaczenia dyrektyw wymiaru kary z art. 53 k.k., problemu „dostosowywania” wysokości kary do potrzeby zastosowania warunkowego zawieszenia, jak i kwestii faktycznego znaczenia, w kontekście przywołanych wcześniej zagadnień, prognozy kryminologicznej.

Odmienne stanowisko w zakresie znaczenia art. 53 k.k. w procesie decydowania o zastosowaniu warunkowego zawieszenia wykonania kary zakłada, że w rozwiązaniu tym nie „,chodzi o wszystkie cele kary, jakie zostały nakreślone w art. 53 k.k. [...]. Nie chodzi zwłaszcza o realizację celu ogólnoprewencyjnego w postaci kształtowania świadomości prawnej społeczeństwa" ${ }^{46}$. Pogląd ten bazuje na tezie, że zastosowanie warunkowego zawieszenia wykonania kary ma być skoncentrowane na realizacji celów względem konkretnego skazanego, w tym celu szczególnoprewencyjnego 47 .

Ciekawą (choć mniej rozpowszechnioną) koncepcję, będącą swoistą „próbą pogodzenia” prezentowanych stanowisk, stanowi ujęcie, które „rozdziela" decyzję o warunkowym zawieszeniu wykonania kary na dwa etapy:

45 D. Kucyper, K. Mamak, W. Płóciennik, Warunkowe zawieszenie wykonania kary w świetle wypowiedzi praktyków wymiaru sprawiedliwości, „Czasopismo Prawa Karnego i Nauk Penalnych" 2017, nr 2, s. 88, 105. Warto zaznaczyć, że w przywołanej publikacji autorzy na wykresie załączonym do cytowanego pytania wskazali, iż odpowiedź „najpierw sąd sprawdza, czy może wymierzyć karę w warunkowym zawieszeniu jej wykonania, a następnie ustala jej wysokość" wybrało $21,4 \%$ respondentów - w tekście głównym dwukrotnie zaznaczyli jednak, iż opcję tę wybrało 69,9\% badanych (w tym $70,6 \%$ sędziów), można więc przyjąć, że prawdopodobnie wkradł się błąd w opracowaniu wykresu.

${ }^{46}$ V. Konarska-Wrzosek, [w:] Kodeks karny. Komentarz, red. V. Konarska-Wrzosek.

${ }^{47}$ Ibidem. 
pierwszy związany z wymiarem kary (i jednocześnie osadzony w kontekście art. 53 k.k.) oraz drugi dotyczący decyzji o zawieszeniu wymierzonej kary (opierający się na szczególnych przesłankach z art. 69 k.k.) ${ }^{48}$. Przywołana koncepcja zakłada, że dyrektywy wymiaru kary uwzględnione na etapie ustalania wysokości kary byłyby ,irrelewantne dla samego warunkowego zawieszenia"49. Wydaje się, że w tym właśnie nurcie wypowiedział się Sąd Apelacyjny w Krakowie w wyroku z dnia 8 grudnia 2015 roku, na łamach którego przywołany organ wskazał, że „orzeczenie o warunkowym zawieszeniu wykonania kary pozbawienia wolności ma charakter wtórny wobec oznaczenia kary wymierzonej z uwzględnieniem dyrektyw jej wymiaru" 50 . Z podobnym ujęciem można się spotkać w wyroku Sądu Apelacyjnego we Wrocławiu z dnia 16 maja 2018 roku. W judykacie tym podkreślono bowiem, że

przepis artykułu 69 § 1 i 2 k.k. jest skonstruowany tak, że przy zastosowaniu instytucji warunkowego zawieszenia wykonania kary nakazuje kierować się jedynie względami szczególnoprewencyjnymi, zaś społeczne oddziaływanie kary, jej współmierność do szkodliwości społecznej czynu i winy sprawcy należy uwzględniać przy wymierzeniu kary (art. $53 \S 1-3$ k.k.) $)^{51}$.

W kontekście propozycji „rozdzielenia” dwóch faz w przedmiocie decydowania o warunkowym zawieszeniu wykonania kary zwraca uwagę rozstrzygniecie Sądu Apelacyjnego w Szczecinie z dnia 30 października 2014 roku. W wyroku tym wskazano, iż ,nie ma automatyzmu między wymierzeniem kary $\mathrm{w}$ wysokości czy rodzaju przewidzianym $\mathrm{w}$ art. $69 \S 1 \mathrm{k} . \mathrm{k}$. a rozważeniem co do potrzeby zastosowania przewidzianej w nim instytucji" 52 . Jak stwierdził sąd, wymiar kary w granicach wyznaczonych w art. 69 k.k. „otwiera [jedynie - K.W.R.] drogę do rozważań nad możliwością zastosowania instytucji przewidzianej w art. 69 $\S 1$ k.k" "53. Wydaje się, że przywołane rozstrzygnięcie wzmacnia znacze-

${ }^{48}$ G. Łabuda, op. cit.

49 Ibidem.

${ }^{50}$ Wyrok Sądu Apelacyjnego w Krakowie z dnia 8 grudnia 2015 roku, II AKa 264/15, online w SIP Lex (dostęp: 7.07.2019).

${ }^{51}$ Wyrok Sądu Apelacyjnego we Wrocławiu z dnia 16 maja 2018 roku, II AKa 101/18, online w SIP Lex (dostęp: 7.07.2019).

52 Wyrok Sądu Apelacyjnego w Szczecinie z dnia 30 października 2014 roku, II AKa 181/14, online w SIP Lex (dostęp: 7.07.2019).

${ }^{53}$ Ibidem. 
nie prognozy kryminologicznej (jako takiej) — przyjmuje bowiem, że o tym, czy kara w określonej wysokości ma przyjąć postać bezwzględną, czy zawieszoną, decyduje ocena, w której z tych dwóch postaci istnieją większe szanse na zrealizowanie wobec sprawcy celów kary, a ocena ta ma wynikać z pozytywnej lub negatywnej prognozy kryminologicznej ${ }^{54}$. W konsekwencji takie ujęcie wzmacnia także znaczenie prognozy kryminologicznej przy warunkowym zawieszeniu wykonania kary, wskazując, iż zastosowanie komentowanej instytucji winno mieć miejsce, gdy prognoza ta jest pozytywna i pozwala przyjąć, że mimo niewykonania kary jej cele wobec sprawcy zostaną osiągnięte.

\section{Bibliografia}

Bojarski T., Komentarz do art. 69 k.k., [w:] Kodeks karny. Komentarz, red. T. Bojarski, wyd. 7, Warszawa 2016.

Goniewicz G., Orzekanie o warunkowym przedterminowym zwolnieniu z odbywania reszty kary pozbawienia wolności po nowelizacji Kodeksu karnego, „Palestra” 2015, nr 7-8.

Goniewicz G., Pozytywna prognoza kryminologiczna jako przesłanka stosowania środków probacyjnych, „Czasopismo Prawa Karnego i Nauk Penalnych” 2017, nr 7.

Hołyst B., Podstawy i zakres indywidualnej prognozy kryminologicznej, „Probacja” 2013, nr 1.

Kalisz T., Warunkowe zwolnienie z reszty kary pozbawienia wolności z perspektywy problemów z ustaleniem treści i kierunku prognozy kryminologicznej, „Nowa Kodyfikacja Prawa Karnego" 30, 2013.

Kodeks karny. Część ogólna, t. 1, cz. 2. Komentarz do art. 53-116, red. W. Wróbel, A. Zoll, wyd. 5, Warszawa 2016.

Kodeks karny. Część ogólna. Komentarz, red. J. Giezek, wyd. 2, Warszawa 2012.

Kodeks karny. Komentarz, red. M. Filar, wyd. 5, Warszawa 2016.

Kodeks karny. Komentarz, red. V. Konarska-Wrzosek, wyd. 2, Warszawa 2018.

Kucyper D., Mamak K., Płóciennik W., Warunkowe zawieszenie wykonania kary w świetle wypowiedzi praktyków wymiaru sprawiedliwości, „Czasopismo Prawa Karnego i Nauk Penalnych" 2017, nr 2.

Marek A., Pojęcie i formy probacji. Zagadnienia ogólne, [w:] System Prawa Karnego, t. 6. Kary i środki karne. Poddanie sprawcy próbie, red. M. Melezini, Warszawa 2010.

Prognozowanie kryminologiczne, red. A. Krukowski, Warszawa 1975.

Prognozowanie kryminologiczne w wymiarze społecznym, red. B. Hołyst, t. 1. Metodologia. Analiza. Tendencje rozwojowe, Warszawa 2017.

${ }^{54}$ Ibidem; analogicznie wyrok Sądu Rejonowego w Mławie z dnia 14 stycznia 2016 roku, II K 323/15, online w SIP Lex (dostęp: 7.07.2019). 
Rękojmia, [hasło w:] Słowniku języka polskiego, red. W. Doroszewski, https://sjp.pwn.pl/ doroszewski/rekojmia;5490144.html.

Rękojmia, [hasło w:] Słownik języka polskiego PWN, https://sjp.pwn.pl/sjp/rekojmia; 2515379.html.

Stępniak P., Udziat skazanego w ksztattowaniu prognozy kryminologicznej, „Przegląd Więziennictwa Polskiego" 2018, nr 61.

Studia z teorii i metodologii prognozowania społecznego. Prognozowanie zachowań, red. A. Siciński, A. Raźniewski, Warszawa 1976.

System Prawa Karnego, t. 6. Kary i środki karne. Poddanie sprawcy próbie, red. M. Melezini, Warszawa 2010.

Warunkowe zawieszenie wykonania kary w założeniach nowej polityki karnej, red. A. Adamski, M. Berent, M. Leciak, Warszawa 2016.

Witkowska-Rozpara K., Warunkowe zawieszenie wykonania kary - uwagi na tle obowiązującej regulacji, praktyki orzeczniczej sądów polskich oraz nowelizacji Kodeksu Karnego (z moca obowiazujaca od 1.07.2015), „Probacja” 2015, nr 2.

Zakrzewski P., Zagadnienie prognozy kryminologicznej, Warszawa 1964.

\section{Akty prawne}

Ustawa z dnia 19 kwietnia 1969 roku — Kodeks karny (Dz.U. z 1969 r. Nr 13, poz. 94 ze zm.).

Ustawa z dnia 6 czerwca 1997 roku — Kodeks karny (Dz.U. z 1997 r. Nr 88, poz. 553 ze zm.).

Strafgesetzbuch (StGB), https://www.gesetze-im-internet.de/stgb/.

Zákon č. 40/2009 Sb. (Zákon trestní zákoník), https://aplikace.mvcr.cz/sbirka-zakonu/ViewFile.aspx type $=\mathrm{c} \& \mathrm{id}=5405$.

\section{Orzecznictwo}

Wyrok Sądu Apelacyjnego w Gdańsku z dnia 27 października 2016 roku, II AKa 162/16. Wyrok Sądu Apelacyjnego w Lublinie z dnia 27 maja 2015 roku, II AKa 97/15.

Wyrok Sądu Apelacyjnego w Łodzi z dnia 13 listopada 2000 roku, II AKa 217/00. Wyrok Sądu Apelacyjnego w Łodzi z dnia 23 listopada 2015 roku, II A Ka 111/15.

Wyrok Sądu Apelacyjnego w Krakowie z dnia 8 grudnia 2015 roku, II AKa 264/15. Wyrok Sądu Apelacyjnego we Wrocławiu z dnia 29 maja 2014 roku, II AKa 136/14. Wyrok Sądu Apelacyjnego we Wrocławiu z dnia 26 lipca 2017 roku, II AKa 178/17. Wyrok Sądu Apelacyjnego we Wrocławiu z dnia 16 maja 2018 roku, II AKa 101/18. Wyrok Sądu Apelacyjnego w Szczecinie z dnia 30 października 2014 roku, II AKa $181 / 14$.

Wyrok Sądu Okręgowego w Poznaniu z dnia 20 marca 2015 roku, IV Ka 166/15. Wyrok Sądu Rejonowego w Giżycku z dnia 29 kwietnia 2019 roku, II K 410/17. Wyrok Sądu Rejonowego w Kętrzynie z dnia 17 maja 2019 roku, II K 195/19. Wyrok Sądu Rejonowego w Mławie z dnia 14 stycznia 2016 roku, II K 323/15. 
Wyrok Sądu Rejonowego w Puławach z dnia 22 maja 2019 roku, II K 1145/18. Wyrok Sądu Rejonowego w Toruniu z dnia 13 maja 2019 roku, VIII K 193/19.

\section{Positive criminological prognosis as the condition of using the conditional suspension of the execution of the penalty - remarks with reference to the concept of ,prognosis" and jurisdiction of Polish courts}

\section{Summary}

The conditional suspension of the execution of the penalty is regulated in Chapter VIII of the Criminal Code of the Republic of Poland. One of the conditions of using this measure is positive criminological prognosis relating to the offender. This study presents the idea of criminological prognosis, the catalogue of factors examined by the court and the meaning of the term "criminological prognosis" in the courts' opinion.

Keywords: conditional suspension of the execution of a penalty, criminological prognosis. 